\title{
Pengaruh Partisipasi Aerobic Exercise Terhadap Pscyhological Wellbeing Pada Dewasa Awal yang Sudah Bekerja
}

\author{
AGENG PINASTI LUTHFAN PRASETYO \& AFIF KURNIAWAN* \\ Departemen Psikologi Klinis dan Kesehatan Mental, Fakultas Psikologi Universitas Airlangga
}

\begin{abstract}
ABSTRAK
Penelitian ini bertujuan untuk mengetahui apakah ada pengaruh partisipasi aerobic exercise terhadap psychological wellbeing pada dewasa awal yang sudah bekerja. Definisi pscyhological wellbeing kondisi individu terbebas dari masalah mental, sedangkan definisi partisipasi aerobic exercise adalah keterlibatan seseorang atau beberapa orang melakukan kegiatan aerobic exercise. Penelitian ini dilakukan pada dewasa awal yang sudah bekerja dengan pertisipan penelitian berjumlah 100 orang berusia 20 - 40 tahun. Alat ukur penelitian ini menggunakan ryff psychological wellbeing scale. Analisis data dilakukan dengan analisis regresi linear sederhana dengan bantuan program statistik SPSS Statistic 22 for Windows. Hasil analisis data menunjukkan bahwa tidak ada pengaruh yang signifikan partisipasi aerobic exercise terhadap psychological wellbeing pada dewasa awal. Partisipasi aerobic exercise berkontribusi pada psychological wellbeing pada dewasa awal yang sudah bekerja sebesar $1 \%$ $\left(R^{2}=0,01\right)$ sedangkan 99\% lainnya dipengaruhi oleh variabel lainnya.
\end{abstract}

Kata kunci: aerobic exercise, psychological wellbeing

\begin{abstract}
This study aims to determine effect of participation aerobic exercise on psychological wellbeing in working early adults. Definition of psychological wellbeing the condition of individual who is free from mental problems, while definition of participation aerobic exercise is the involvement of a person or several people doing activities aerobic exercise. This research was conducted in early adults who have worked with research participants amounting to 100 people aged 20-40 years. The measuring instrument of this research uses ryff psychological wellbeing scale. Data analysis was performed using simple linear regression analysis with the help of the statistical program SPSS Statistic 22 for Windows. The results of data analysis showed that there was no significant effect of participation aerobic exercise on psychological wellbeing in early adulthood. Participation in aerobic exercise contributed to psychological wellbeing in early adults had worked by $1 \%\left(R^{2}=0.01\right)$ while the other $99 \%$ were influenced by other variables.
\end{abstract}

Keywords: aerobic exercise, psychological wellbeing

Buletin Penelitian Psikologi dan Kesehatan Mental (BRPKM), 2021, Vol. 1(1), 52-58

*Alamat korespondensi: Fakultas Psikologi Universitas Airlangga, Kampus B Universitas Airlangga Jalan Airlangga 4-6 Surabaya 60286. Surel: afif.kurniawan@psikologi.unair.ac.id Naskah ini merupakan naskah dengan akses terbuka dibawah ketentuan the Creative Common Attribution License (CC-BY-4.0) (http://creativecommons.org/licenses/by/4.0), sehingga penggunaan, distribusi, reproduksi dalam media apapun atas artikel ini tidak dibatasi, selama sumber aslinya disitir dengan baik. 


\section{PEN D A H U L U A N}

Pandemi COVID 19 menyebabkan menurunnya kondisi perekonomian sebagian masyarakat Indonesia. Hal ini dapat mengakibatkan turun nya nilai kesehatan, baik fisik maupun psikologis (Damian, 2020). Kesehatan yaitu salah satu unsur sangat penting pada kehidupan seseorang. Kesehatan adalah suatu keadaan fisik, mental, sosial yang diiringi tanpa adanya keluhan sama sekali (cacat atau sakit) pada diri individu tersebut (WHO, 2014). Kondisi perekonomian yang menurun, banyak sekali permasalahanpermasalahan yang menekan pikiran, sehingga dapat menyebabkan berbagai gangguan psikologis terutama pada tahap perkembangan dewasa awal. Permasalahan yang sering muncul pada individu tahap perkembangan dewasa awal adalah mengenai pekerjaan (bekerja) dan menikah (Hurlock, 2004). Papalia, dkk., (2012) mengatakan dewasa awal merupakan tahap dari perkembangan setelah tahap remaja akhir dimana tahap ini dimulai dari usia 20-40 tahun. Pada usia 20-30 tahun individu dewasa awal lebih berpusat pada mencari kerja dan memilih pasangan hidup (Hurlock, 2004).

Pekerjaan merupakan salah satu tugas perkembangan yang penting bagi dewasa awal, terutama bagi laki-laki karena dia akan menjadi kepala keluarga yang memberikan nafkah kepada keluarga. Hal ini didukung dari beberapa penelitian sebelumnya yang mengatakan sebanyak 60\% individu dewasa awal yang telah menerima pekerjaan merasa sulit buat mendapatkan keseimbangan antara pekerjaan serta keluarga (Handayani, 2013). Individu pada tahap perkembangan dewasa awal dapat merasakan kelelahan, rasa bersalah, dan menguras energi untuk dapat menyeimbangkan antara tuntutan dari kedua peran tersebut yaitu pekerjaan dan keluarga (Ariyanti, 2009). Christine, dkk., (2010) mengatakan adanya tuntutan pekerjaan yang dimiliki individu pada dewasa awal tersebut membuat waktu dan tenaga untuk keluarga semakin berkurang dan menyebabkan munculnya berbagai macam konflik di lingkungan keluarganya akibat waktu dan tenaga yang berkurang. Pendapat diatas merupakan konflikkonflik yang terjadi pada tahap dewasa awal yang sudah bekerja tersebut dapat menyebabkan menurunnya psychological wellbeing (kesejahteraan psikologis).

Permasalahan lain yang dialami individu pada tahap perkembangan dewasa awal diantaranya; penentuan identitas diri dengan kekaburan identitas Jika pada tahap ini terdapat masalah, individu mungkin akan menghadapi kekaburan identitas. Lalu ada masalah kemandirian dengan tidak mandiri dalam mengurus diri sendiri dalam kehidupan sehari-hari. Berikutnya muncul juga permasalahan mengenai keraguan akan sukses tidaknya meniti jenjang pendidikan dan karir. Ada juga permasalahan berikutnya akankah individu tersebut akan menikah, terlambat menikah atau tidak menikah. Permasalahan terakhir yang dihadapi dewasa awal mengenai hubungan sosial yang sehat (banyak teman) dengan hubungan sosial yang tidak sehat menarik diri (sedikit teman) (Bagus, 2019). Selain permasalahan yang dialami di dalam indiviu pada tahap perkembangan dewasa awal diatas ada juga permasalahan yang harus dihadapi di luar individu, yaitu tingginya persaingan untuk mendapatkan pekerjaan. Pada saat ini persaingan mendapatkan pekerjaan merupakan suatu permasalahan yang serius. Lowongan pekerjaan yang terbatas dengan jumlah pencari kerja yang begitu banyak akan menimbulkan peluang seseorang diterima di suatu perusahaan sangat kecil. Bagi individu yang belum menerima pekerjaan akan membuat kegiatan sehari-harinya menjadi terganggu yang bisa menurunkan taraf psychological wellbeing (Junaidy, 2014).

Dalam kesehatan psikologi dikenal adanya variable psychological wellbeing untuk mengetahui tingkat kesejahteraan psikologis invidu. Kesejahteraan psikologis (psychological wellbeing) yakni keadaan dimana ketika individu mengalami sebuah kebebasan dari tekanan ataupun dari sebuah masalah mental yang telah dialaminya, namun, individu tersebut cenderung lebih yakni keadaan dimana memiliki kemampuan menerima diri ataupun sejarah dari kehidupannya (self-acceptance), perkembangan diri (personal growth), sebuah keyakinan yang akan dimiliki oleh kebanyakan individu untuk memberikan

Buletin Riset Psikologi dan Kesehatan Mental (BRPKM) 2021, Vol. 1(1), 52-58 
suatu arahan bahwa hidupnya adalah sebuah tujuan dan ia hidup juga karena memiliki sebuah tujuan ( $p$ urpose in life), mempunyai sebuah standarisasi sebuah hubungan yang cenderung baik ataupun positif dengan para individu lainya (positive relationship with others), potensi guna memberikan arahan untuk hidupnya serta lingkungan dari kehidupanya dengan semaksimal mungkin (environmental mastery), keahlian yang dimiliki individu untuk memutuskan sebuah keputusan dari tindakan nya sendiri (autonomy)(Ryff \& Keyes, 1995). Psychological wellbeing mengikutsertakan beragam aspek kehidupan, salah satunya yakni aspek pekerjaan. Seseorang yang memiliki psychological wellbeing yang rendah mengembangkan perasaan tidak puas terhadap diri sendiri, memiliki sedikit hubungan dengan orang lain dan dapat dipercaya, merasa sulit untuk hangat, mengkonfirmasi tekanan sosial untuk berfikir dan bertindak dengan cara tertentu menurut dirinya, kesulitan dalam mengatur kegiatan sehari-hari, hanya memiliki sedikit tujuan atau target, tidak memiliki tujuan hidup/target yang ingin dicapai, tidak melihat adanya manfaat dari masa lalu kehidupanya, dan tidak mampu mengembangkan sikap dan perilaku yang baru, mempunyai perasaan sebagai pribadi yang stagnan (Djabumir, 2016).

Berdasarkan penjelasan di atas, diperlukan suatu usaha untuk menjaga atau meningkatkan kesehatan individu baik fisik maupun psikologi. Individu pada usia dewasa awal dapat meningkatkan psychological wellbeing dengan melakukan olahraga aerobic exercise, tidur, jalan-jalan (Cleveland, 2020). Latihan aerobik yakni sebuah bentuk kegiatan fisik yang mengaitkan otot - otot besar serta dilaksanakan pada intensitas cukup rendah serta pada waktu yang cukup lama (Sherwood, 2001). Partisipasi aerobic exercise adalah keterlibatan seseorang atau beberapa orang melakukan kegiatan aerobic exercise. Pada saat melakukan partisipasi aerobic exercise sistem pada tubuh yang mendukung dalam melakukan aerobic exercise, yaitu sistem saraf, sistem endokrin, respiratori,volume darah, jantung, dan sirkulasi (Sharkey, 2003). Udatha, dkk., (2020) mengatakan latihan aerobik telah terbukti memiliki dampak yang signifikan pada umumnya dan kesejahteraan kesehatan mental individu. Hal ini memberikan sebuah landasan yang kuat untuk dapat menerapkan latihan aerobik sebagai rutinitas dalam perawatan pasien dengan berbagai kondisi kesehatan mental bersama dengan diberikan pengobatan secara rutin.

Shaw, dkk., (2005) mengatakan latihan yang dapat mengurangi tingkat kecemasan, depresi, stres, serta meningkatkan kualitas dengan meningkatkan kesejahteraan psikologis yakni melaksanakan aerobic exercise seperti ; joging, bersepeda, renang, berjalan, bahkan naik turun tangga yang dilakukan dengan teratur dan secara progresif. Selain penelitian diatas juga ditemukan bahwa, dengan melakukan latihan dengan teratur memberikan dampak positif dalam mengurangi depresi dan perasaan cemas (Weinberg \& Gould, 2011). Manfaat positif dalam melakukan aktifitas berolahraga yaitu dalam hal meningkatkan kesehatan dan kesejahteraan psikologis individu maupun masyarakat (Nisa \& Jannah, 2018). Apabila individu rutin melakukan olahraga akan dapat meningkatkan kesehatan bagi dirinya dan juga akan meningkatkan kesejahteraan psikologis (psychological wellbeing).

Penelitian ini diharapkan mampu memberikan pengetahuan apakah partisipasi aerobic exercise mempunyai pengaruh terhadap psychological wellbeing pada dewasa awal yang sudah bekerja. Terdapat dua hipotesis dalam penelitian ini, yakni ; (1) Tidak adanya pengaruh partisipasi aerobic exercise terhadap psychological wellbeing pada dewasa awal yang sudah bekerja. (2) adanya pengaruh partisipasi aerobic exercise terhadap psychological wellbeing pada dewasa awal yang sudah bekerja.

\section{E T ODE}

Penelitian ini menggunakan tipe penelitian kuantitatif dengan pendekatan tipe explanatory research. Dimana tujuan dari penelitian eksplanasi adalah menjelaskan hubungan, pengaruh, maupun perbedaan antar satu variabel dengan variabel lain. Dalam penelitian ini, penulis ingin melihat apakah adanya 
pengaruh partisipasi aerobic exercise terhadap psychological wellbeing pada dewasa awal yang bekerja. Dalam penelitian ini, populasi partisipan yang digunakan adalah dewasa awal yang sudah bekerja. Kriteria partisipan pada penelitian ini adalah : (1) berusia 20-40 tahun, (2) sudah bekerja, (3) minimal jam kerja 1 jam/hari, (4) melakukan aerobic exercise (bersepeda, berenang, jogging, berjalan) minimal 1 kali dalam seminggu.

Teknik sampling yang digunakan dalam penelitian ini adalah non-probabilitas sampling dengan teknik purposive sampling. Jumlah sampel partisipan pada penelitian ini diambil berdasarkan pada metode dan rumus yaitu perhitungan sampel menggunakan aplikasi GPower. Hasil penghitungan data dengan jenis tes linear multiple regression: fixed model, $R 2$ deviation from zero didapatkan angka sebesar 89 . Hal ini menunjukkan bahwa jumlah minimal sampel yang dibutuhkan adalah 89 orang. Partisipan dalam penelitian ini akan mengisi form informed consent dimana data dari penelitian ini aman dan akan dipakai untuk kepentingan penelitian. Dalam penelitian ini, penulis mendapatkan 100 partisipan pada penelitian ini $(M=27.4 ; S D=1.10)$ yang merupakan dewasa awal sudah bekerja.

Teknik pengumpulan data pada penelitian ini menggunakan kuesioner. Kuesioner terdiri dari data mengenai partisipasi aerobic exercise serta skala psychological wellbeing. Kuesioner dari partisipasi aerobic exercise berisikan pertanyaan jenis kelamin, usia, jenis pekerjaan, jenis aerobic exercise apa yang dilakukan dan frekuensi partisipasi dalam aerobic exercise. Jenis skala yang digunakan dalam penelitian ini adalah skala likert yaitu Ryff Psychological Wellbeing Scale yang disusun oleh (Ryff \& Keyes, 1995) untuk variabel psychological wellbeing. Pada alat ukur Ryff Psychological Wellbeing Scale terdapat 42 item dengan 6 pilihan jawaban dengan skor (1 ="sangat tidak setuju", 6 = "sangat setuju") dengan nilai koefisien reliabilitas yang baik $\alpha=0,857$. Pada skala psychological wellbeing terdapat pernyataan favorable dan unfavorable. Sebelum melakukan analisis regresi linear sederhana, dilakukan uji asumsi data. Uji asumsi data meliputi ; uji normalitas, uji homogenitas, uji linearitas, uji heterokedasitas. Setelah dilakukan uji asumsi baru kemudian dilakukan pengujian hipotesis dengan menggunakan analisis regresi linear sederhana. Uji asumsi dan uji hipotesis dilakukan dengan bantuan aplikasi SPSS Statistic 22 for Windows.

\section{HAS I L P EN ELITIA N}

Hasil analisis deskriptif menunjukkan jumlah $(N=100)$ partisipan yang dianalisa dari setiap skala. Skor terendah (Min) partisipasi aerobic exercise dari data partisipan sebesar 1 sedangkan nilai tertingginya (Max) 3, dan rata-rata (Mean) sebesar 2,05. Pada psychological wellbeing, nilai terendah (Min) adalah 149, nilai tertingginya (Max) adalah 236, dan rata-rata (Mean) sebesar 181,07. Sebagian besar partisipan penelitian memiliki tingkat psychological wellbeing kategori sedang, yaitu sebanyak 66 orang (66\%). Sedangkan partisipan penelitian yang memiliki tingkat psychological wellbeing kategori rendah sebanyak 18 orang (18\%), dan partisipan yang memiliki tingkat psychological wellbeing kategori tinggi sebanyak 16 orang $(16 \%)$.

Berdasarkan hasil uji korelasi diketahui bahwa partisipasi aerobic exercise berkorelasi positif dan cenderung sangat lemah $(r(100)=0,098 ; p>0.334)$ dengan psychological wellbeing. Berdasarkan analisis regresi linear sederhana dapat diketahui bahwa predictor atau variabel bebas memiliki nilai $(F(1$, 98)=0.944; $p>0,334 ; R^{2}=0.010$ ) dan varians independen dapat menjelaskan 1 persen dari varians variabel dependen. Partisipasi aerobic exercise $(B=2,365 ; S E=2,434 ; t=0,971 ; p>0,334)$ menunjukkan nilai yang positif, sehingga ketika partisipasi aerobic exercise meningkat, maka psychological wellbeing juga akan meningkat. 
Berdasarkan hasil analisis yang telah diuraikan diatas diperoleh hasil bahwa variabel $(\mathrm{X})$ partisipasi aerobic exercise tidak berpengaruh secara signifikan terhadap psychological wellbeing $(\mathrm{Y})$ dewasa awal yang sudah bekerja, sehingga hipotesis dalam penelitian ini ditolak. Tidak adanya pengaruh partisipasi aerobic exercise terhadap pscyhological wellbeing pada dewasa awal yang sudah bekerja dikarenakan ; mayoritas subjek penelitian ini berusia 36 - 40 tahun sebesar 35\% (35 orang). Pada usia tersebut permasalahan tidak hanya dari dunia kerja saja melainkan juga dari keluarga, dimana pada usia diatas, mayoritas sudah berkeluarga (Hurlock, 2004). Hal ini sesuai dengan Kiky \& Jeannyver (2018) yang mengatakan pada usia 30 individu akan mengalami puncak dari psychological wellbeing dan setelah itu akan menurun seiring bertambahnya usia. Sebanyak 39\% subjek penelitian melakukan partisipasi aerobic exercise sebanyak 3 - 4x seminggu. Jenis pekerjaan mayoritas adalah pegawai swasta sebesar $30 \%$ dan jenis mayoritas aerobic exercise adalah berenang sebesar 31\%. Dimana pada usia tersebut individu akan lebih banyak memiliki banyak permasalahan dilingkungan kantor maupun lingkungan keluarganya (Junaidy, 2014). Jenis pekerjaan swasta ini juga bisa menjadi faktor mengapa dewasa awal yang sudah melakukan aerobic exercise hanya akan menaikkan sedikit psychological wellbeing.

Hasil dari penelitian ini, juga terjadi di penelitian yang dilakukan oleh peneliti sebelumnya Pertiwi (2016) yang mengatakan tidak adanya pengaruh aerobic exercise terhadap psychological wellbeing pada mahasiswa. Hal ini ditunjukkan dengan nilai korelasi antar variabel pada data pada penelitian tersebut memiliki nilai signifikansi sebesar 0,614 >0,05 yang memiliki arti tidak adanya pengaruh antara aerobic exercise terhadap psychological wellbeing pada mahasiswa sedangkan nilai pengaruh pada penelitian ini sebesar $2 \%$ saja yang memiliki arti 98\% lainnya dipengaruhi oleh variabel yang tidak diteliti. Untuk dapat meningkatkan tingkat psychological wellbeing dapat juga menggunakan cara coping yakni dengan problem focus coping dan emotional focus coping (Pertiwi, 2016). Aerobic exercise merupakan salah satu cara diantara banyak yang cara yang bisa dilakukan sebagai emotion focused coping. Untuk meningkatkan psychological wellbeing juga dibutuhkan dapat melakukan problem focus coping. Oleh sebabnya, maka aerobic exercise akan menjadi hanya memiliki sebuah satu pilihan buat menaikkan psyychological wellbeing, adapun banyaknya aspek aspek yang memungkinkan untuk sangat dibutuhkan guna memberi peningkatan pada psychological wellbeing.

\section{S I M P U L A N}

Tujuan penelitian ini adalah untuk mengukur pengaruh partisipasi aerobic exercise terhadap psychological wellbeing. Analisis data hasil penelitian menyatakan bahwa tidak ada pengaruh yang signifikan partisipasi aerobic exercise terhadap psychological wellbeing. Variabel partisipasi aerobic exercise berkontribusi terhadap psychological wellbeing pada dewasa awal sebesar 1\%. Hal ini menandakan 99\% sisanya dipengaruhi oleh variabel lain yang tidak diteliti dalam penelitian ini. Berdasarkan hasil penelitian, saran yang dapat diberikan bagi peneliti selanjutnya antara lain adalah: Guna mendapatkan hasil yang lebih baik, disarankan peneliti selanjutnya menggunakan lebih banyak responden dengan sebaran yang lebih merata, serta waktu yang cukup.

Berdasarkan saran tersebut diharapkan hasil penelitian dapat digeneralisasikan. Selain menggunakan survey, disarankan untuk penelitian selanjutnya menggunakan metode eksperimen sebagai pembanding. Diharapkan ada perbandingan penelitian antara penelitian menggunakan metode survey dengan menggunakan metode eksperimen dalam waktu yang sama. Disarankan peneliti selanjutnya untuk mempertimbangkan variabel lain yang mungkin bisa memberi pengaruh pada psychological wellbeing dewasa awal. Diharapkan hasil yang didapat lebih baik. 
Pada kondisi saat ini yang sedang mengalami penurunan ekonomi, dimana dunia usaha akan melakukan tindakan efisiensi dalam menjalankan usahanya. Tentunya hal ini akan berakibat pada tuntutan kepada pelaku usaha, terutama kepada individu dewasa awal untuk bisa memenuhi tuntutan yang ada. Hal ini akan menimbulkan tekanan psikologis kepada individu dewasa awal, sehingga berpengaruh pada tingkat psychological wellbeing. Diharapkan kepada instansi terkait, dalam hal ini perusahaan dan pemerintah, untuk memberikan kesempatan atau waktu dan pengetahuan akan manfaat olahraga kepada karyawan, khususnya aerobic exercise bagi kesehatan mental dan wellbeing. Sehingga dengan meningkatnya kesehatan mental karyawan, produktifitas perusahaan akan meningkat.

\section{U C A P A N T E R I MAKASIH}

Penulis mengucapkan banyak terimakasih kepada dosen pembimbing yaitu bapak Afif Kurniawan, M.Psi., Psikolog, yang telah membimbing penulis dari selama penelitian. Penulis juga mengucapkan banyak terimaksih kepada partisipan yang telah bersedia untuk berpartisipasi dalam penelitian penulis. Tanpa adanya partisipan penelitian yang bersedia meluangkan waktu dalam berpartisipasi skirpsi ini tidak dapat berjalan dengan baik.

\section{DEKLARASI POTENSI TERJADINYAKONFLIK KEPENTINGAN}

Ageng Pinasti Luthfan Prasetyo dan Afif Kurniawan tidak bekerja, menjadi konsultan, memiliki saham, atau menerima dana dari perusahaan atau organisasi manapun yang mungkin akan mengambil untung dari diterbitkannya naskah ini.

\section{DAFTAR PUSTAKA}

Ariyanti, E. (2009). Gambaran konflik peran pada ibu bekerja yang barupertama kali memiliki anak (Skripsi). Depok: Universitas Indonesia.

Bagus, A. (2019). PROBLEMATIKA SOSIAL MAHASISWA DI UNIVERSITAS NEGERI DITINJAU DARI PERSPEKTIF PERKEMBANGAN PSIKOSOSIAL. Fakultas Psikologi Universitas Malang.

Christine, W., Oktorina, M., \& Mula, I. (2010). "Pengaruh Konflik Pekerjaan dan Konflik Keluarga Terhadap Kinerja dengan Konflik Pekerjaan KeluargaSebagai Intervening Variabel (Studi pada Dual Career Couple di Jabodetabek)". Jurnal Manajemen dan Kewirausahaan, Vol 12 No. 2, hal 121-132.

Cleveland, C. (2020, 9 7). Cleveland Clinic. Retrieved 11 30, 2020, from Cleveland Clinic: https://my.clevelandclinic.org/health/articles/7050-aerobic-exercise

Damian. (2020, April 24). Virus corona: Efek psikologis setelah kehilangan pekerjaan selama pandemi Covid-19. Retrieved November 10, 2020, from BBC: https://www.bbc.com/indonesia/vert-cap52408458 
Djabumir, N. (2016). Hubungan antara Family Functioning dan Psychological Well being pada Emerging Adulthood. Jurnal Ilmiah Mahasiswa Universitas Surabaya, 5(1, 1-16.

Handayani, A. (2013). Keseimbangan Kerja Keluarga pada Perempuan Bekerja : Tinjauan Teori Border. Jurnal Psikologi Vol.21 No.2.

Hurlock, E. B. (2004). Psikologi Perkembangan Suatu Pendekatan Sepanjang Rentang Kehidupan. Jakarta: Erlangga, edisi kelima.

Junaidy, D. (2014). Perbedaan kualitas hidup pada dewasa awal yang bekerja dan yang tidak bekerja. Jurnal Psikologi Industri dan Organisasi, 102-107.

Kiky, D. H., \& Jeannyver, T. (2018). Psychological Well-being Of Employees In Java, Indonesia. Jurnal Muara Ilmu Sosial, Humaniora, dan Seni Vol. 2, No. 2, Oktober 2018:, 597 -605.

Nisa, A. F., \& Jannah, M. (2018). Hubungan Antara Partisipasi Olahraga Senam Aerobik Dan Psychological Well Being Pada Dewasa Awal. Jurnal Psikologi Pendidikan 5, 1-5.

Papalia, D., Feldman, R., \& Martorel, G. (2012). Developmental Psychology Experience Human Development. New York: McGraw Hill; 12th edition.

Pertiwi, G. S. (2016). Pengaruh Durasi Aerobic Exercisedan Frekuensi Aerobic Exercise pada Psychological Wellbeing pada Mahasiswa dengan Beban Akademik Tinggi. Skripsi.

Ryff, C., \& Keyes, C. (1995). The Structure of Psychological Well-Being Revisited. Journal of Personality and Social Psychology Vol. 69, 719-727.

Sharkey, J. S. (2003). Kebugaran dan Kesehatan. Jakarta: PT Raja Grafindo Persada.

Shaw, D., Gorely, T., \& Corban, R. (2005). Instant notes, sport and exercise psychology. New York, USA: Garland Science/BIOS Scientific Publishers.

Sherwood, L. (2001). Fisiologi manusia : dari sel ke sistem. Jakarta: ECG.

Udatha, T. R., Judith, A., \& Kasturi, A. (2020). Effect of aerobic exercises on depressive symptoms, anxiety, self-esteem, and quality of life among adults with depression. Clinical Epidemiology and Global Health journal homepage: www.elsevier.com/locate/cegh.

Weinberg, R., \& Gould, D. (2011). Foundations of sport and exercise psychology 5 th ed. USA: Human Kinetics.

WHO. (2014). Social determinants of mental health. Geneva: World Health Organization. 